\title{
MODELING OF REINFORCED CONCRETE BEAMS WITH AND WITHOUT OPENING BY USING ANSYS
}

\author{
OSMAN M. RAMADAN ${ }^{1}$, SAYED M. ABDELBAKI', \\ AHMED M. SALEH ${ }^{3}$ AND ABDULKAREEM Y. ALKHATTABI ${ }^{4}$ \\ 1 Professor, Faculty of Engineering, Cairo University \\ 2 Professor, National Housing and Building Research Center \\ 3 Associate Professor, Faculty of Engineering, Cairo University \\ 4 Graduate Student, Cairo University
}

(Received May 11, 2009 Accepted May 31, 2009)

\begin{abstract}
This paper presents the procedures of constructing an ANSYS nonlinear finite element model for reinforced concrete beam analysis. This model was used to analyze reinforced concrete beams with and without openings. The results were compared with the experimental results of fullscale laboratory tests made experimentally. Beams strength, stiffness, deformed shape, and cracking patterns were investigated. The comparison between experimental and analytical results showed acceptable agreement.
\end{abstract}

KEYWORDS: reinforced concrete, beams, web openings, shear, finite elements, ANSYS

\section{INTRODUCTION}

The experimental tests of reinforced concrete members cost a lot of money, time and effort. This was a reason of research limitation and made the study of all aspects a very hard mission. These difficulties have been overcome by simulating reinforced concrete members and analyzing them numerically. The finite element method was used to construct an analytical model of reinforced concrete beams with and without openings. The common finite element analysis software, ANSYS, was used to conduct this study. The strength, stiffness and cracking pattern of analyzed beams were carefully investigated. The results were compared with test results of full scale reinforced concrete beams with same geometry and details manufactured and experimentally tested by the authors.

\section{FINITE ELEMENT METHOD}

The Finite Element Method (FEM) involves dividing the complex domain into finite elements and uses variational concepts to construct an approximation of the solution. There are two types of analysis: 2-D modeling and 3-D modeling. A 2-D modeling is simple, can be run on normal computers but may give less accurate results on some applications. However, a 3-D modeling produces more accurate results while sacrificing the ability to run effectively on all but the fastest computers. Within each of these modeling schemes, numerous algorithms (functions) can be inserted to make the system behave linearly or non-linearly. Linear systems are far less complex and 
generally do not take into account plastic deformation. Non-linear systems do account for plastic deformation, and many also are capable of analyze a material all the way to fracture.

\section{ANALYSIS COMPUTER PROGRAMS}

A number of computer program packages have been developed for the solution of finite element problems. Among the more widely used packages are ANSYS, NASTRAN, ADINA, LS-DYNA, MARC, SAP, COSMOS, ABAQUS, and NISA. The latest version of ANSYS, ANSYS11 multiphysics, was chosen to be used in this research work. It is capable in modeling nonmetal materials and effective to model reinforced concrete as a non-homogeneous material with nonlinear response. It has also the capability to predict and display the patterns of cracking and crushing of the material.

\section{ANSYS FINITE ELEMENT MODEL}

Modeling of reinforced concrete in ANSYS starts by choosing one of three methods that can be used to model steel reinforcement in finite element models. These methods are (Figure 1): 1) discrete method; 2) embedded method; and 3) smeared method.

In the discrete method, reinforcement is modeled using bar or beam elements connected to the concrete mesh nodes. As a result, there are shared nodes between the concrete mesh and the reinforcement mesh, as shown in Figure 1a. Also, since the reinforcement is superimposed in the concrete mesh, concrete exists in the same regions occupied by the reinforcement.

To overcome mesh dependency in the discrete model, the embedded formulation allows independent choice of concrete mesh, as shown in Figure 1b. In the embedded method, the stiffness of the reinforcing elements is evaluated independently from the concrete elements, but the element is built into the concrete mesh in such a way that its displacements are compatible with those of surrounding concrete elements. That is, the concrete elements and their intersection points with each reinforcement segment are identified and used to establish the nodal locations of the reinforcement elements.

In the smeared method, it is assumed that reinforcement is uniformly spread throughout the concrete element in a defined region of the finite element mesh. This approach is used for large-scale models where the reinforcement does not significantly contribution to the overall response of the structure (Figure 1c).

For this research work, the discrete method was chosen to model steel reinforcement in the finite element model of reinforced concrete beam. The finite element model itself can be created in ANSYS using command prompt line input, the Graphical User Interface (GUI), or ANSYS Parametric Design Language (APDL). APDL was used for creating the models in this paper. 


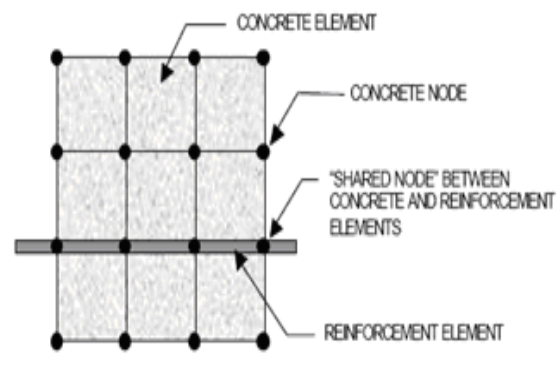

a) discrete method

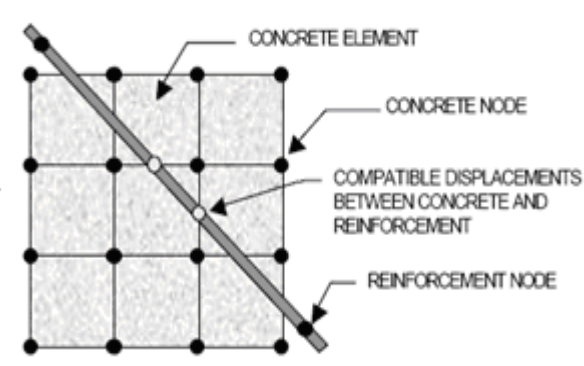

b) embedded method

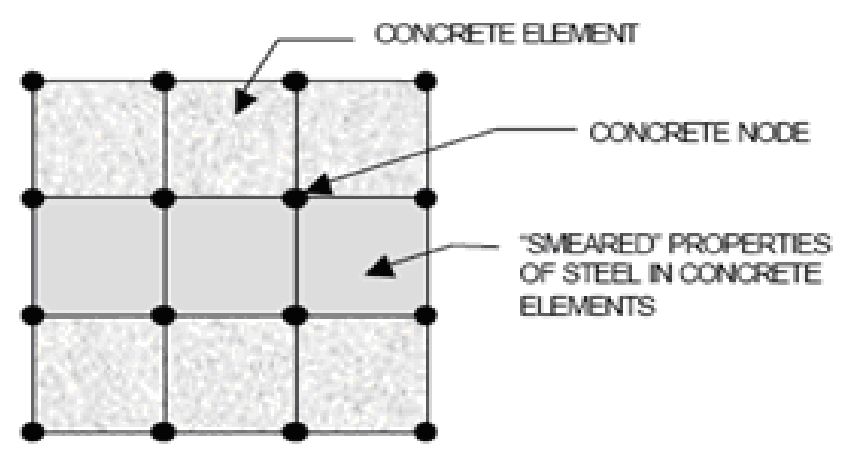

c) smeared method

Figure 1: Reinforcement modeling methods [11]

\section{CRACKING AND CRUSHING INDICATIONS}

ANSYS, the finite element analysis software used in this study, has the capability to predict and display cracking and crushing in the reinforced concrete member due to loading. The concrete element, solid65, has eight integration points positioned at a distance less a little bit of the element length. Cracking and crushing can be drawn in the integration points or the average value can be drawn at the element centeroid. Cracking is shown with circle outline in the plane of the crack, and crushing is shown with an octahedron outline. If the crack has opened and then closed, the circle outline will have an $X$ through it. Each integration point can crack in up to three different planes perpendicular to the principal axes. The first crack at an integration point is shown with a red circle outline, the second crack with a green outline, and the third crack with a blue outline.

\section{MODELING OF REINFORCED CONCRETE BY ANSYS}

\subsection{Introduction}

Descriptions of the procedures, commands, elements, and theoretical details are included in the manuals of the ANSYS product documentation set. ANSYS, Inc. Theory Reference [5, 6] provides the theoretical basis for calculations in the ANSYS 
program, such as elements, solvers and results formulations, material models, and analysis methods to show how it uses the input data to calculate the output. It also explains how to deduce results and describes the relationship between input data and output results produced by the program. The program can account for concrete material nonlinearity including cracking and crushing capability. Only the concrete element (SOLID65) supports the concrete model. Plasticity theory provides a mathematical relationship that characterizes the elasto-plastic response of materials. There are three ingredients in the rate-independent plasticity theory: the yield rule criterion, flow rule, and the hardening rule.

The yield criterion determines the stress level at which yielding is initiated. For multi-component stresses, this is represented as a function of the individual components, $\mathrm{f}(\{\sigma\})$, which can be interpreted as an equivalent stress $\sigma_{\mathrm{e}}$ :

Where:

$$
\sigma_{\mathrm{e}}=\mathrm{f}(\{\sigma\})
$$

\section{$\{\sigma\}=$ stress vector}

When the equivalent stress is equal to a material yield parameter $\sigma_{\mathrm{y}}$, i.e. $\sigma_{\mathrm{e}}=\mathrm{f}(\{\sigma\})=\sigma_{\mathrm{y}}$, the material will develop plastic strains. If $\sigma_{\mathrm{e}}$ is less than $\sigma_{\mathrm{y}}$, the material is elastic and the stresses will develop according to the elastic stress-strain relations. Stress-strain behavior of multilinear isotropic plasticity option is shown in Figure 2.

The flow rule determines the direction of plastic straining. The hardening rule describes the changing of the yield surface with progressive yielding. Two hardening rules are available: work (or isotropic) hardening and kinematic hardening. In work hardening, the yield surface remains centered about its initial centerline and expand in size as the plastic strains develop (Figure 3a). For materials with isotropic plastic behavior this is termed isotropic hardening. Kinematic hardening assumes that the yield surface remains constant in size and the surface translates in stress space with progressive yielding (Figure 3b). The Multilinear Isotropic Hardening (MISO) plasticity option uses VonMieses/Hill yield criteria. Figure 4 shows the yield surfaces for different material models.

\subsection{Modeling Procedures}

The discrete method, available in ANSYS, for modeling reinforced concrete is utilized. In this method, solid elements with cracking, crushing and plasticity capabilities are used to model concrete whereas link members with plasticity capability are used for steel bars.

\subsubsection{Element Types}

Concrete was modeled in ANSYS by an eight-node solid element, Solid65, which has eight nodes with three degrees of freedom per node: translations in $\mathrm{x}, \mathrm{y}$, and $\mathrm{z}$ directions. This element has the capabilities of cracking, crushing and deforming plastically. Steel reinforcement was modeled by a 3-D link element, Link8, which needs two nodes and has three degrees of freedom for each node as translations in $\mathrm{x}, \mathrm{y}$ and $\mathrm{z}$ directions. The element is capable of plastic deformation. Steel plates were used at support and loading points. These steel plates were modeled by eight-node solid elements, Solid45. The geometry of elements type Solid 65, Link 8 and Solid45 are shown in Figures 5a, 5b and 5c, respectively. 


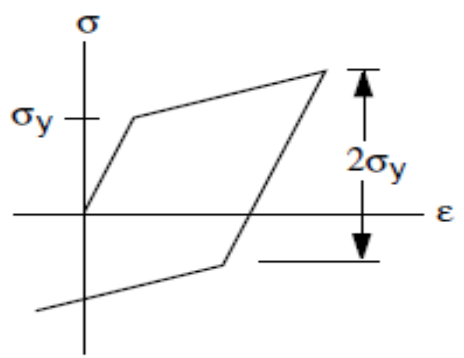

(a) Bilinear Kinematic

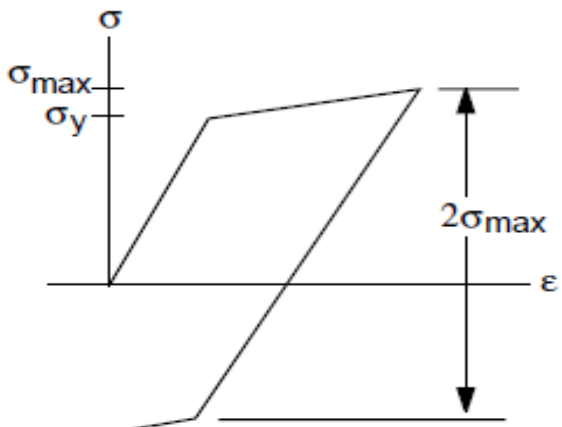

(c) Bilinear Isotropic

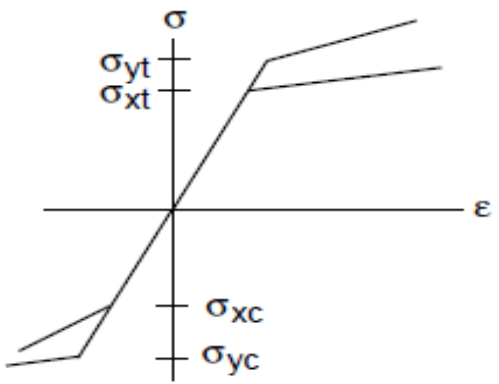

(e) Anisotropic
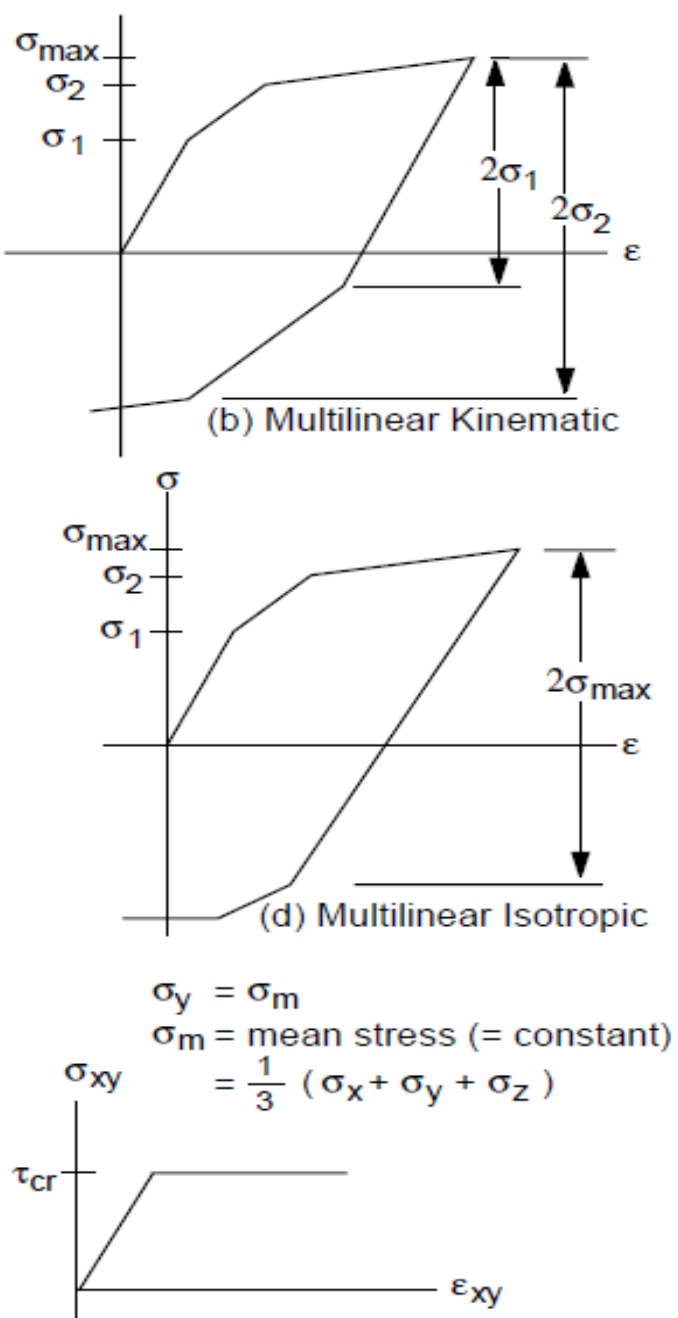

(f) Drucker-Prager

Figure 2: Stress-strain behavior for plasticity options [7]

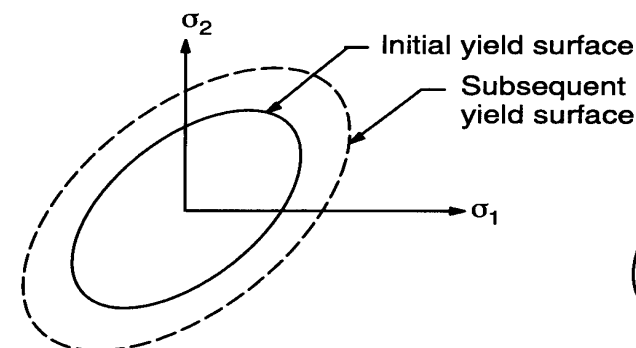

(a) Isotropic Work Hardening

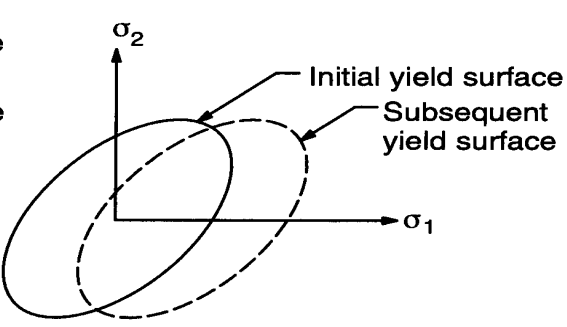

(b) Kinematic Hardening

Figure 3:Hardening rules [7] 


\subsubsection{Material Properties}

Concrete is defined as multi-linear isotropic material. The idealized stress-strain curves for concrete and steel recommended by the Egyptian code [10] were utilized taking $\gamma_{\mathrm{c}}=\gamma_{\mathrm{s}}=1$ and allowing concrete to resist some tensile stresses. The steel is defined by a bilinear elastic-perfectly plastic stress-strain relation. The idealized stress-strain curves for concrete and steel used are shown in Figures 6. The material constants for concrete are as follows:

1. Concrete properties:

- Shear transfer coefficient for open crack $\beta_{o p}=0.3$

- $\quad$ Shear transfer coefficient for closed crack $\beta_{c l}=0.9$

- Ultimate uniaxial tensile strength-modulus of rapture $f_{c t r}=0.6 \sqrt{f_{c u}}=3 \mathrm{~N} / \mathrm{mm}^{2}$

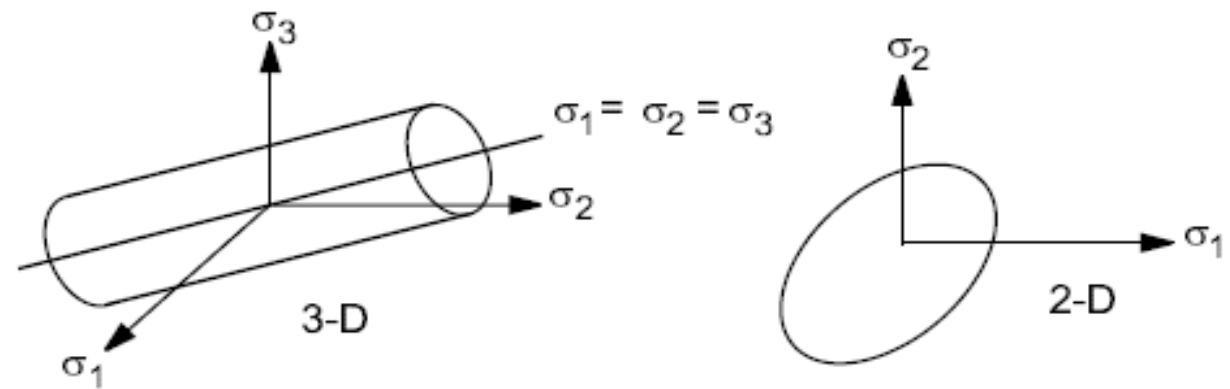

(a) Kinematic Hardening
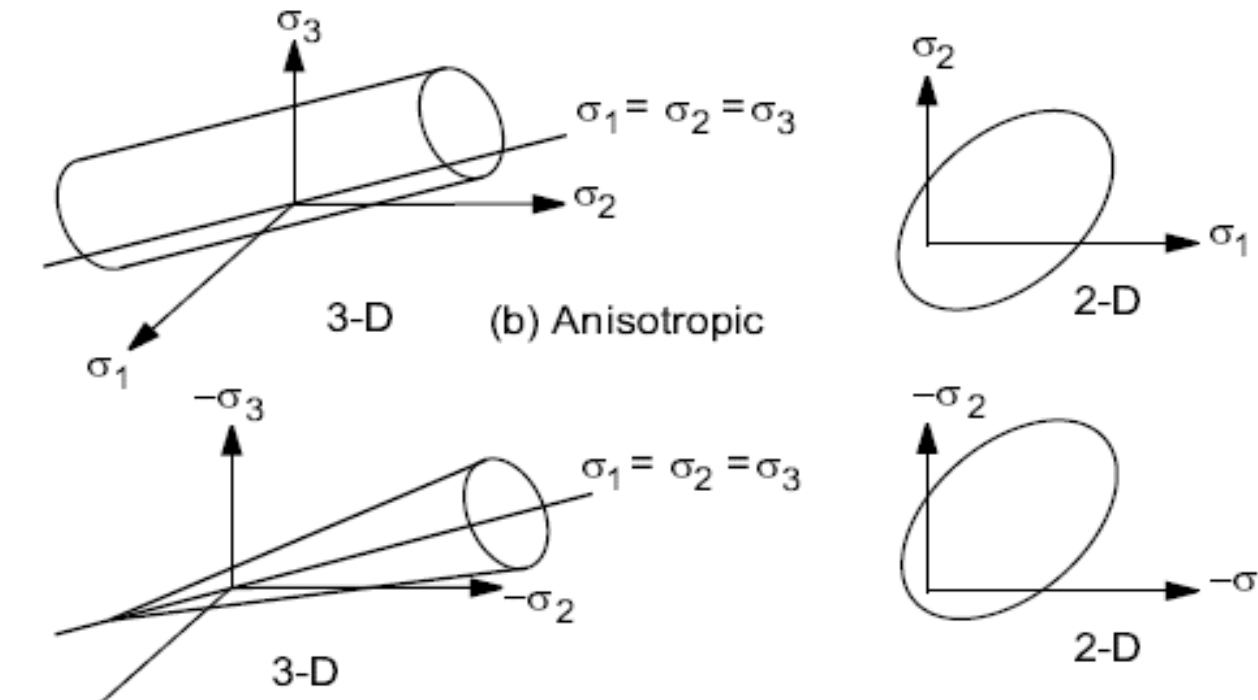

(c) Drucker-Prager

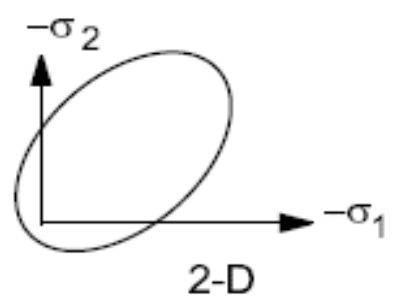

Figure 4:Yield surfaces [7] 


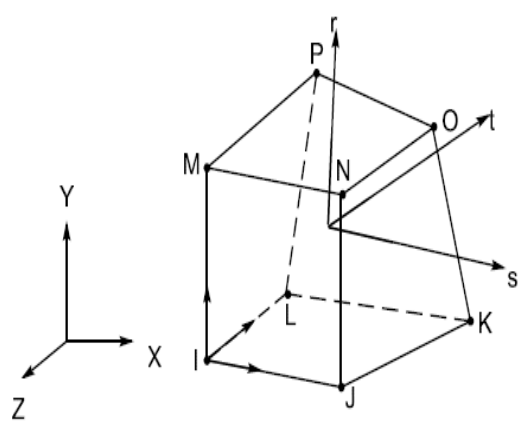

a) Solid65
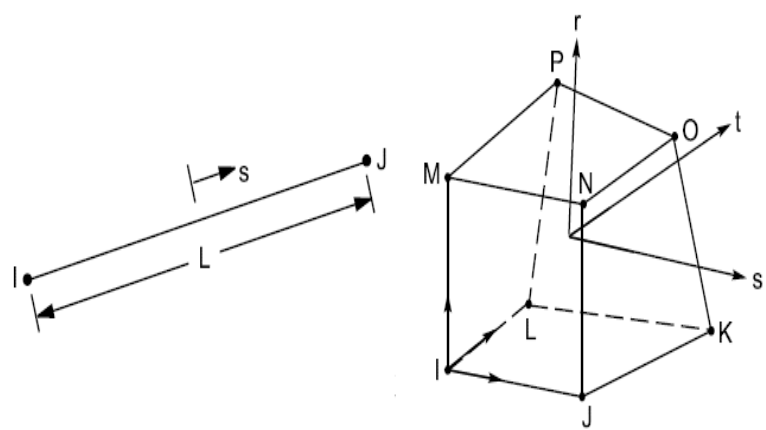

c) Solid45

Figure 5: Geometry for utilized finite element types

- Ultimate uniaxial compressive strength $f_{c u}=30 \mathrm{~N} / \mathrm{mm}^{2}$

- Modulus of elasticity $E_{c}=24100 \mathrm{~N} / \mathrm{mm}^{2}$

- $\quad$ Poisson's ratio for concrete $v_{c}=0.2$

2. Reinforcing steel properties:

- Initial modulus of elasticity $E_{s}=200000 \mathrm{~N} / \mathrm{mm}^{2}$

- Yield stress $f_{y}=360 \mathrm{~N} / \mathrm{mm} 2$

- Poisson's ratio for steel $v_{s}=0.3$

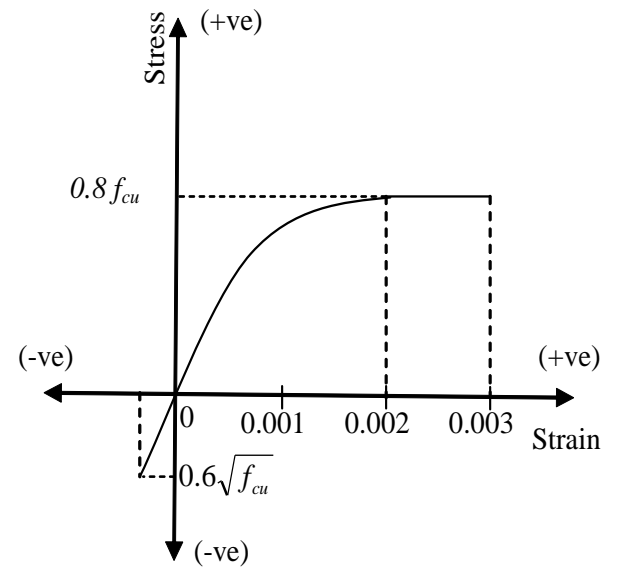

a) for concrete

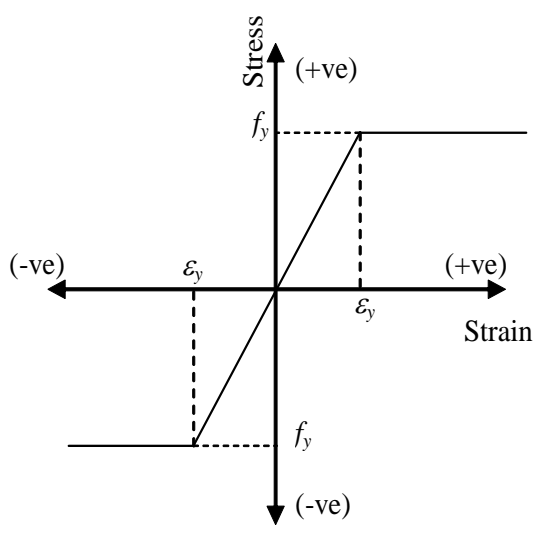

b) for steel

Figure 6: Idealized stress-strain curves used in analysis

\subsubsection{Geometry}

Taking advantage of symmetry of the beams about XY plane, only one half of the beam was modeled. This reduces computational time and computer disk space requirements. Nodes were constructed to produce concrete elements, link elements 
were then added on the existing nodes. Element dimensions for concrete and steel plates were chosen to be $20 \times 20 \times 20 \mathrm{~mm}$ and $20 \times 20 \times 40 \mathrm{~mm}$, whereas reinforcement bar elements were chosen to be $20 \mathrm{~mm}$ in length.

\subsubsection{Solution}

Each beam was loaded by a monotonically increasing load applied as a line load in the middle of the steel plate located at the midspan of the top face as shown in Figure 7. Proper displacement boundary conditions were applied on all nodes on the symmetry plane. One support line was modeled as hinged support allowing rotation only while the other was modeled as a roller support allowing both rotation and horizontal translation.

\section{MODELING VERIFICATION}

The results of two full-scale reinforced concrete beams tested experimentally by the authors were compared to the theoretical results obtained by analyzing same beams by the above described ANSYS model. Both beams had a span of $2200 \mathrm{~mm}$, a width of $120 \mathrm{~mm}$, and a total of $320 \mathrm{~mm}$. Beam B1 was without opening while beam B2 was with an opening $360 \times 80 \mathrm{~mm}$ in the shear span of it. The geometrical and reinforcement details are shown in Figures 7 and 8.

Experimental and theoretical results of the beams B1 and B2 were compared to verify the accuracy of the modeling. The tested beams were prepared from local materials and tested under a monotonically increasing load at its midspan till failure. Full details of the experimental program as well as theoretical investigation can be found elsewhere [4].

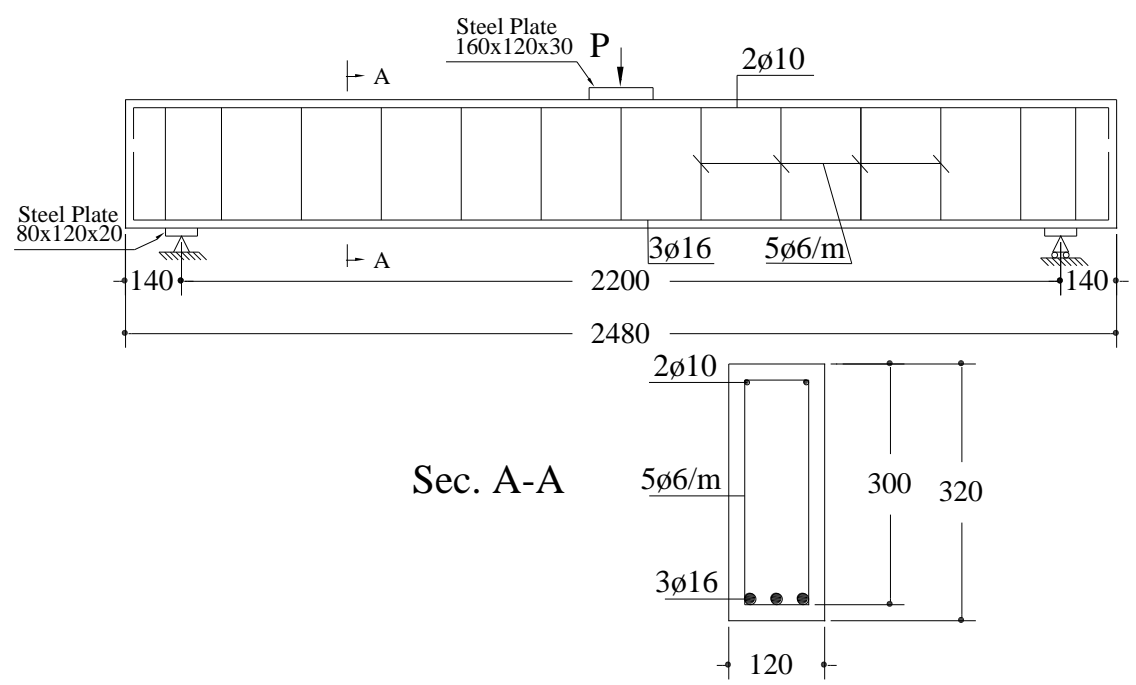

Figure 7: Details of beam B1 


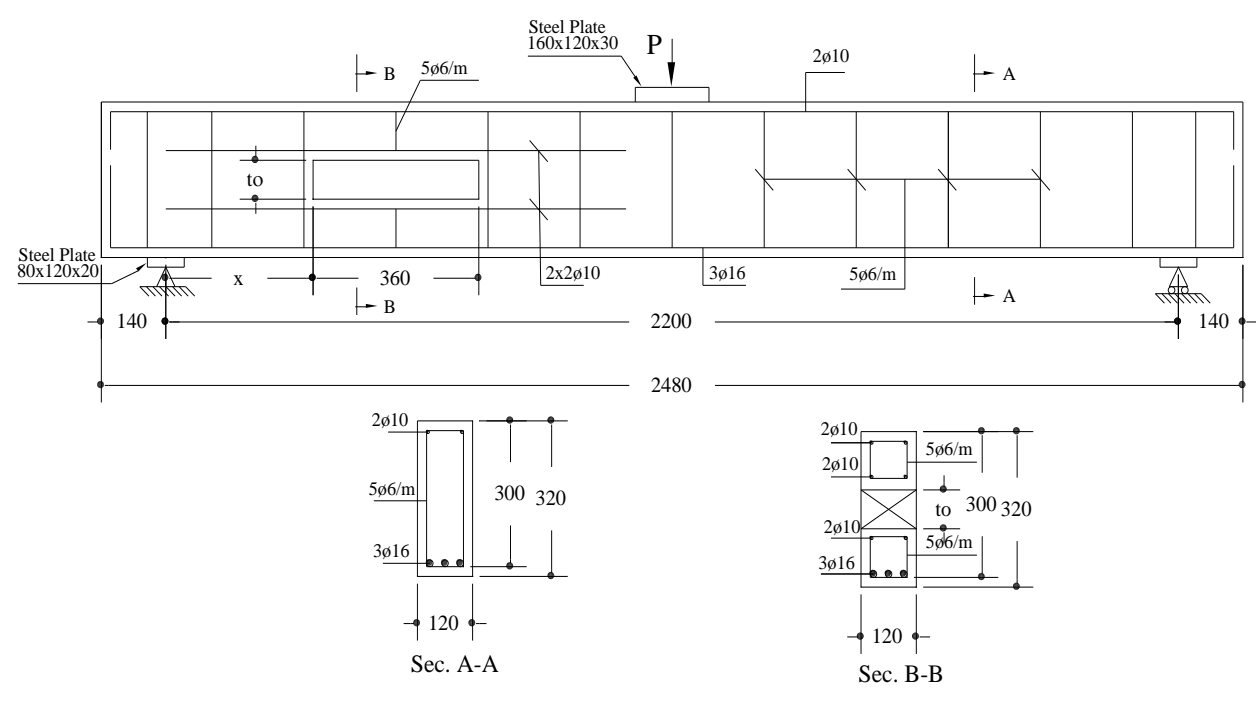

Figure 8: Details of beam B2

\subsection{Beam B1}

Load deflection curves obtained both experimentally and numerically are shown in Figure 9. Experimental and numerical deflection lines along beam span at different load levels are shown in Figure 10. The failure modes for beam B1 are compared in Figure 11.

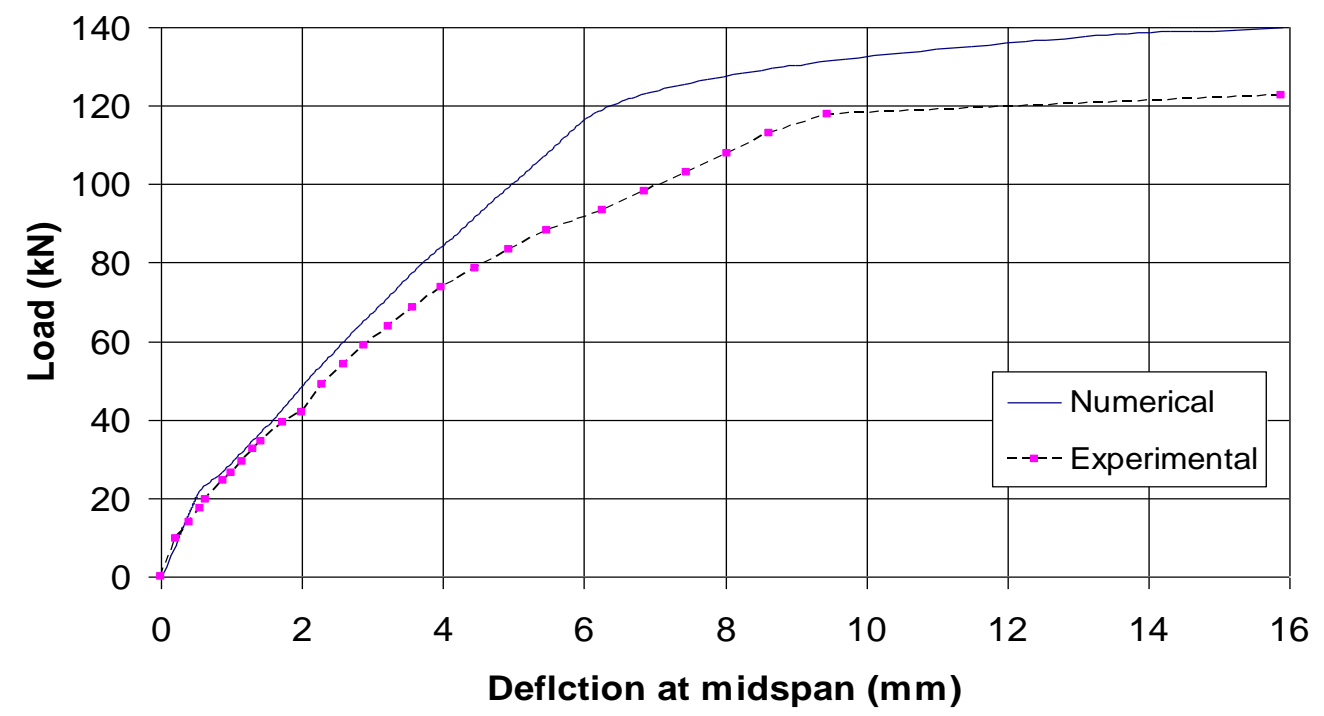

Figure 9: Load deflection curve for beam (B1) 


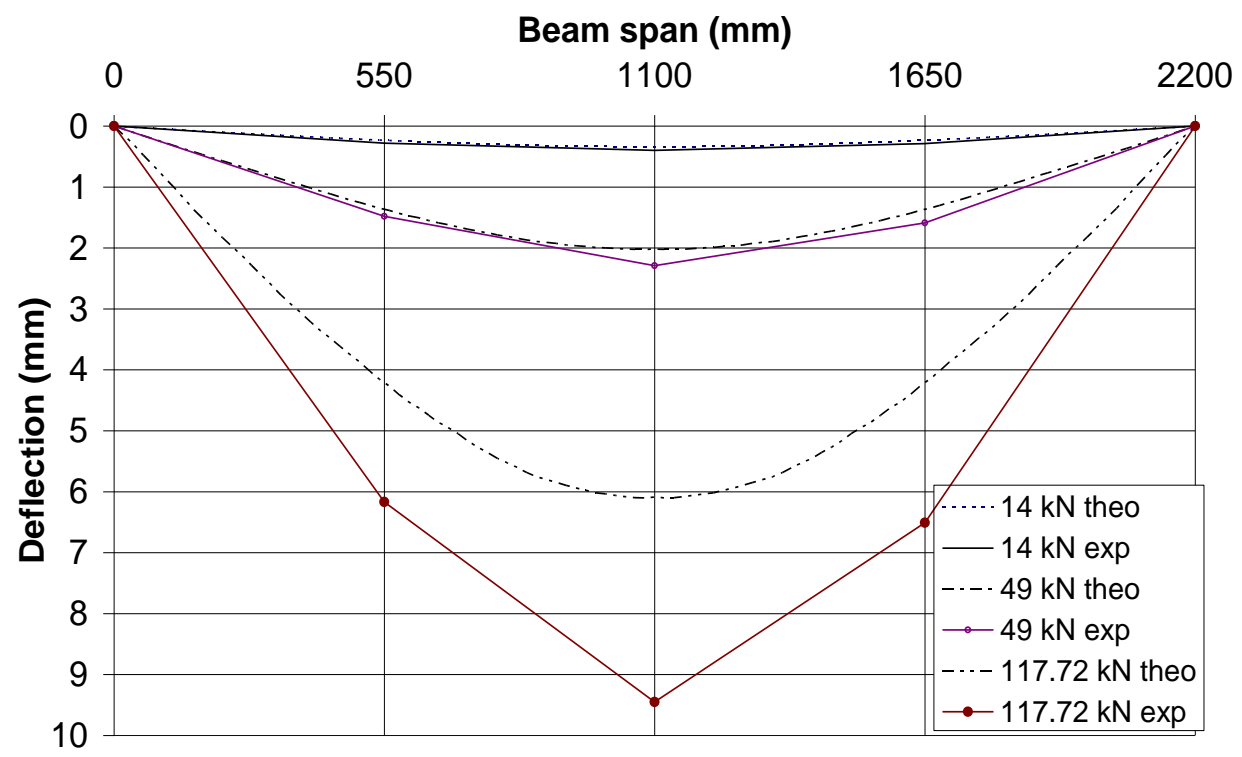

Figure 10: Deflection lines for beam (B1)

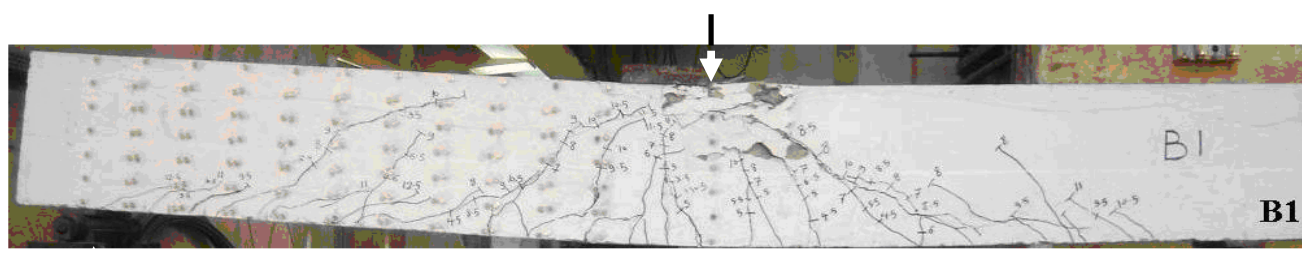

I

(a)

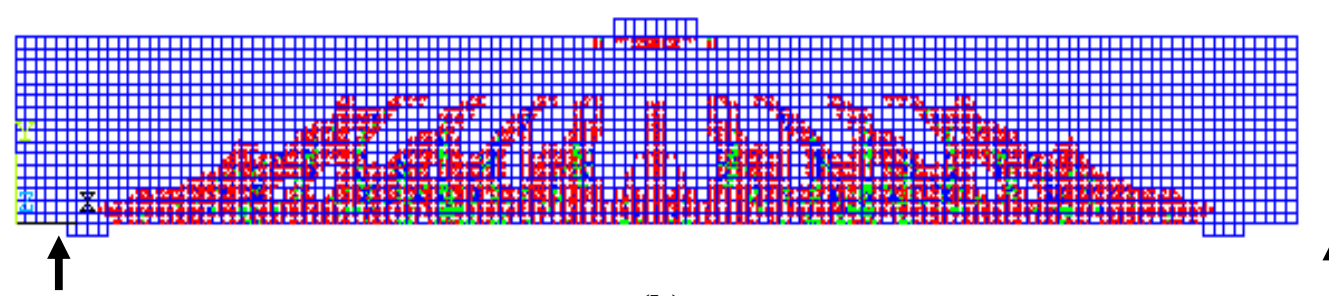

(b)

Figure 11: Failure mode: a) Experimental; b) Numerical

As seen from Figures 9 and 10, the numerical simulations produce close behavior to the experimental measurements up to about $70 \%$ of the ultimate load. Then, the model predicts a stiffer behavior and a higher strength. The cracking and crushing patterns shown in Figure 11 are reasonably close. The observed stiffening effect can be attributed to the constant shear retention factor used throughout the loading history. This is clearly not the case in reality where shear transfer across cracks deteriorates with increasing crack width. 


\subsection{Beam B2}

Figure 12 compares the load deflection curves obtained experimentally to the numerically calculated one. Also the experimental and numerical deflection lines along beam span at different load levels are shown in Figure 13. Finally, Figure 14 presents the failure modes of the tested beams and its theoretical prediction. The comparison between numerical and experimental results for beam (B2) leads to similar conclusions as discussed above for beam (B1). It is therefore concluded that the adopted modeling is capable of close representation of the actual beams.

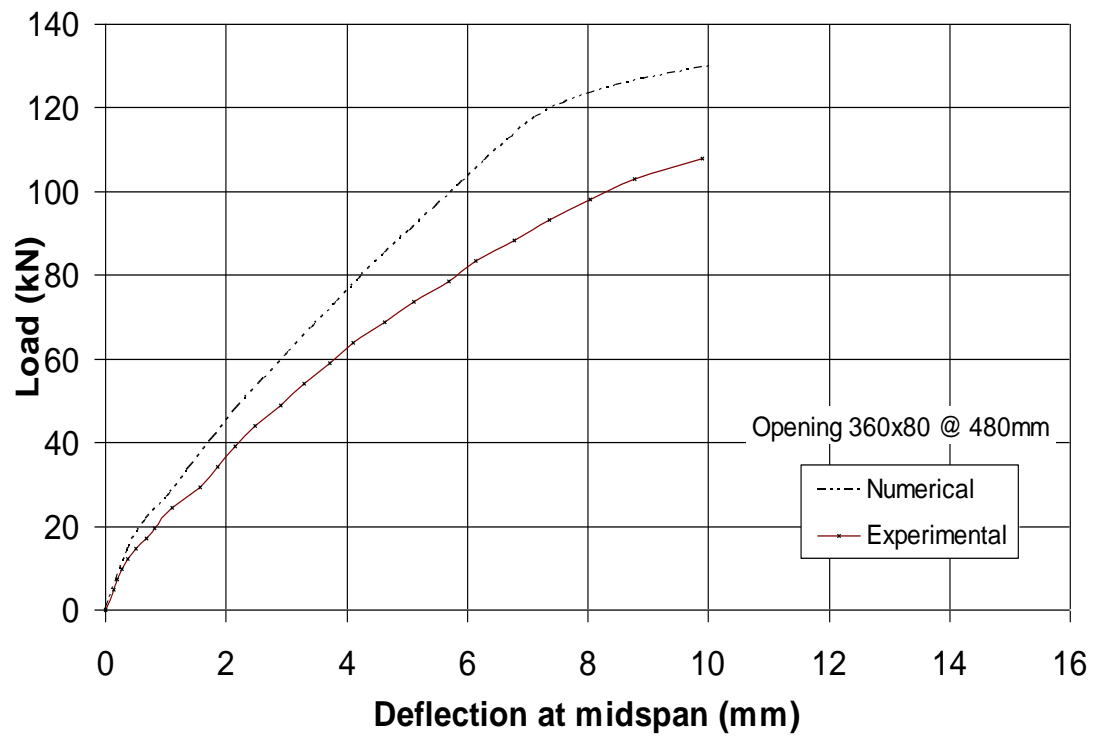

Figure 12: Load deflection curve for beam (B2)

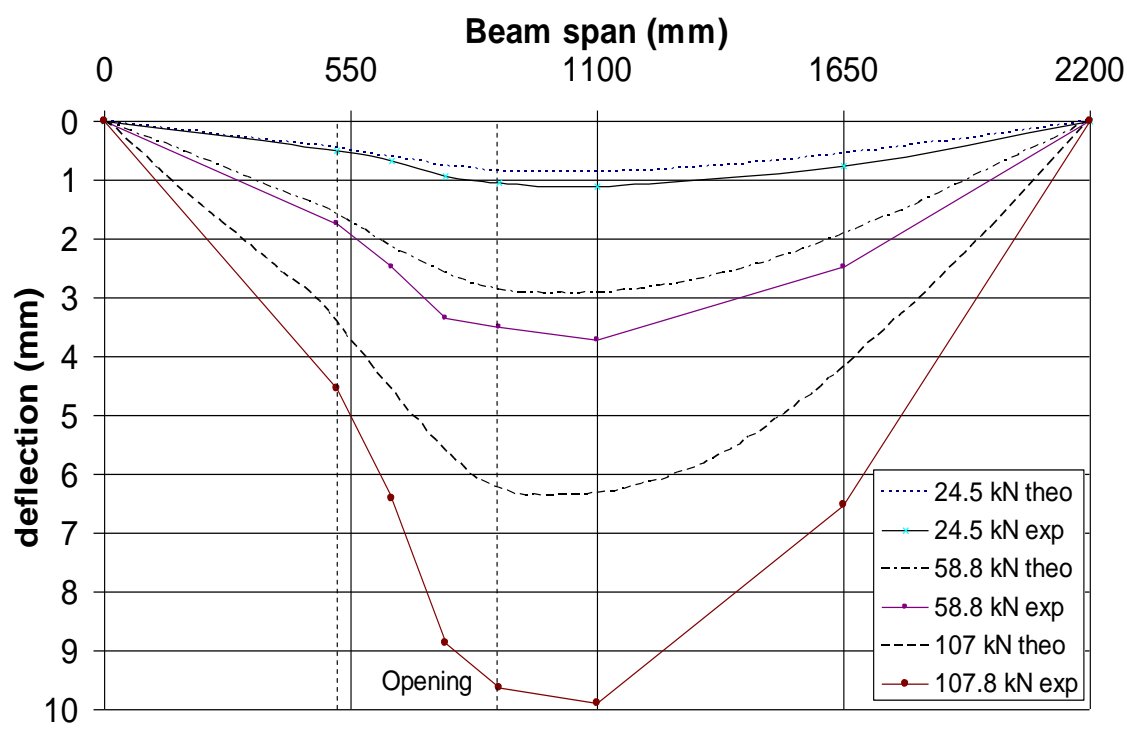

Figure 13: Deflection lines for beam (B2) 


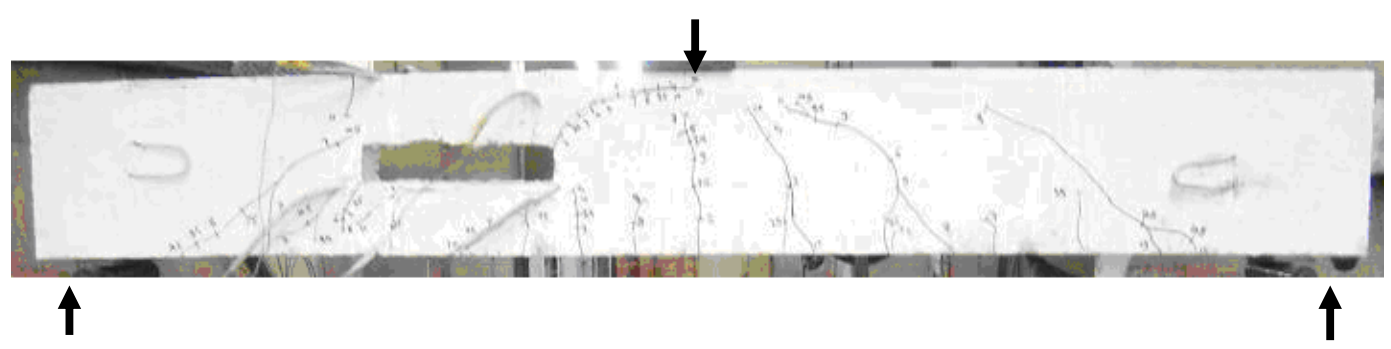

(a)

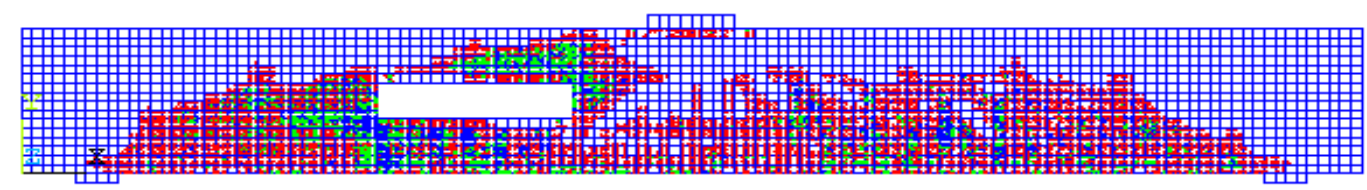

(b)

Figure 14: Failure mode of B2: a) Experimental; b) Numerical

\section{RESULTS SUMMARY}

The results are summarized in this section. Table 1 contains the experimental and theoretical values of cracking load, failure load and corresponding deflection values.

Table 1: Comparison between Experimental and Theoretical Results

\begin{tabular}{|c|c|c|c|c|}
\hline $\mathbf{t}$ & & & B1 & B2 \\
\hline \multirow{6}{*}{$\begin{array}{l}\text { At first } \\
\text { crack }\end{array}$} & \multirow{3}{*}{$\operatorname{Load}(k N)$} & Experimental & 24.5 & 14.7 \\
\hline & & Theoretical & 20.7 & 13.6 \\
\hline & & Deviation & $16 \%$ & $8 \%$ \\
\hline & \multirow{3}{*}{ Deflection (mm) } & Experimental & 0.88 & 0.51 \\
\hline & & Theoretical & 0.53 & 0.36 \\
\hline & & Deviation & $40 \%$ & $30 \%$ \\
\hline \multirow{6}{*}{ At failure } & \multirow{3}{*}{ Load $(k N)$} & Experimental & 127.5 & 107.8 \\
\hline & & Theoretical & 149.0 & 107.0 \\
\hline & & Deviation & $14 \%$ & $1 \%$ \\
\hline & \multirow{3}{*}{ Deflection (mm) } & Experimental & 16.9 & 8.8 \\
\hline & & Theoretical & 15.8 & 6.3 \\
\hline & & Deviation & $14 \%$ & $29 \%$ \\
\hline
\end{tabular}

\section{CONCLUSIONS}

The nonlinear behavior of reinforced concrete beams can be simulated by the three dimensional ANSYS modeling. The analysis of reinforced concrete members by finite elements method and ANSYS computer program could save a lot of money, time and effort and give a chance to study aspects which was hard to be conducted in the experimental studies. Based on the analysis of the experimental and theoretical results, the following remarks can be made: 
1. Detailed theoretical background and procedures of preparing a nonlinear finite element ANSYS model for reinforced concrete beam, with and without openings were presented.

2. The comparison between the experimental and theoretical results with respect to strength, stiffness, deformed shape and cracking patterns showed satisfactory agreement.

3. For the analyzed beams, the presence of opening decreased the beam initial and ultimate strengths by $40 \%$ and $20 \%$, respectively. At the same time, the stiffness was decreased by $20 \%$. The maximum deflection point was shifted a little bit to the side of the opening because of the presence of the opening.

Finally, the finite element model verified in this paper can now be used in additional studies to investigate the effect of the change in the opening dimension and location in the reinforced concrete beam and also to study enhancement solutions such as increasing stirrups or using diagonal bars around the opening etc.

\section{REFERENCES}

1. Abdalla, H. A.; Torky, A. M.; Haggag H. A.; and Abu-Amirah, A.F. (2003), "Design Against Cracking at Openings in Reinforced Concrete Beams Strengthened with Composite Sheets",Composite Structures, No. 60, pp.197-204.

2. ACI Committee 318 (2007), "Building Code Requirements for Reinforced concrete (ACI 318-2007) and Commentary (ACI 318R-2007)", American Concrete Institute, Detroit, USA.

3. Abu-Amirah, A. F. M. (2003), "Strengthening of Reinforced Concrete Beams with Openings Using FRP Sheets", Cairo University, Giza, Egypt.

4. Al Khattabi, A. Y., (2009), "Openings in Reinforced Concrete Beams (Experimental Study and Theoretical Analysis)", PhD Thesis, Cairo University, Giza, Egypt (to appear).

5. Al-Shaarbaf, I. A. S., Al-Bayati, N. A-M. J., (2007), "Nonlinear Finite Element Analysis of Reinforced Concrete Beams with Large Opening under Flexure". Eng. \& Technology, vol.25, No.2, Baghdad, Iraq, pp. 210-228.

6. ANSYS Inc. (2006), "ANSYS Multiphysics-Finite Element Analysis SoftwareVersion 11.0" Canonsburg, Pennsylvania, USA.

7. ANSYS (2006), ANSYS user's Manual Revision 11.0, ANSYS Inc., Canonsburg, Pennsylvania, USA.

8. Chen, W., F., "Plasticity in Reinforced Concrete", McGraw-Hill, Inc., USA, (1982).

9. Ding, W. Q.; Yue, Z. Q.; Tham, L. G. Zhu, H. H.; Lee, C. F. and Hashimoto, T. (2004) "Analysis of shield tunnel", Inter. J. for Numerical and Analytical Methods in Geomechanics, Vol. 28, Issue 1, P: 57-91.

10. Egyptian Code for Design and Construction of Reinforced Concrete Structures ECCS 203-2007, Cairo, Egypt.

11. Hamdy, M. W. O. (1991), "Effect of Openings Shapes at the Shear Span on the Behavior of Prestressed Beams", MSc. Thesis, Ain Shams University.

12. Kachlakev, D. I. (2002), "Finite Element Analysis and Model Validation of Shear Deficient Reinforced Concrete Beams Strengthened with GFRP Laminates", Paper 
002, Third International Conference on Composites in Infrastructure, San Francisco, California, June 10-12.

13. Mansur, M.A.; Huang, L. M.; Tan, K. H.; and Lee, S. L. (1992), "Deflection of Reinforced Concrete Beams with Web Openings", ACI Structural Journal, V. 89 No. 4, July-Aug., pp. 391-397.

14. Mansur, M.A.; and Tan, K. H., "Concrete Beams with Openings: Analysis and Design", CRC Press LLC, Boca Raton, Florida, USA, (1999), 224pp.

15. Masti, k., Maghsoudi, A. A., and Rahgozar, R., (2008), "Nonlinear Models and Experimental Investigation of Lifetime History of HSC Flexural Beams", American journal of Applied Science 5 (3), USA, pp 248-262.

16. Nasser, K. W.; Acavalos, A.; and Daniel H. R. (1967), "Behavior of Large Openings in Reinforced Concrete Beams", ACI Structural Journal, V. 64, No. 3 , January, pp. 25-33.

17. Ramadan, O.M.O. and Kansouh, H. (2007). "Openings in Pure Bending Zone of High Strength Concrete Beams," Engrg. Res. J., Fac. of Engrg., Helwan Univ., 112, August, pp C14-C35.

18. Ramadan, O.M.O. and Kansouh, H. (2006). " Openings in Pure Bending Zone of HSC Beams," Scientific Bulletin, Faculty of Engineering, Ain-Shams University, Vol. 41(3), pp 93-109.

19. Tan, K. H.; and Mansur, M.A. (1996), "Design Procedures for Reinforced Concrete Beams with Large Web Openings", ACI Structural Journal, V. 93 No. 4, July-Aug., pp. 404-411.

\section{نمذجة التحليل الإنشائي لكمرات الخرسانة المسلحة باستخدام (ANSYS)}

إنِّ تحليل عناصر الخرسانة المسلحة بطريقة العناصر المحددة يوفر الكثير من الوقت والجهد والمال كونه اختبار غير مكلف وغير متلف ويعطي نتائج مقبولة وبه يمكن دراسة جوانب لم يكن من السهل إجرائها معملياً. ويفصل هذا البحث خطوات إعداد نموذج لتحليل كمرات الخرسانة المسلحة باستخدام برنامج ANSYS وتطبيق ذلك على كمرتين من الخرسانة المسلحة في إحداهما فتحة في منطقة القص. حيث أن لبرنامج ANSYS القدرة على تمثيل الخرسانة كمادة غير متجانسة وتسلك سلوكاً لا خطياً

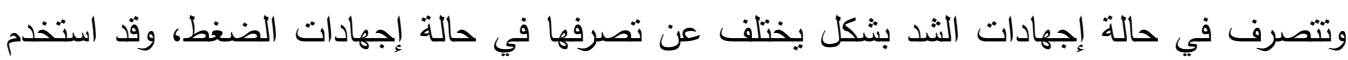
العنصر Solid65 لتمثيل الخرسانة والعنصر Link8 لتمثيل أسياخ صلب التسليح. أجري تحليل الكمرات على أنها ترتكز ارتكازا بسيطا على لوحين من الصلب عند نقطتي الارتكاز وتحت تأثثر حمل

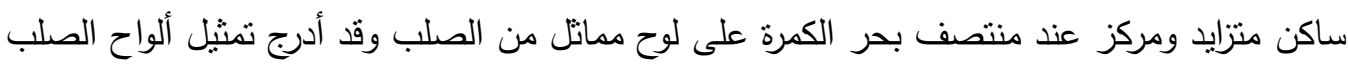
أيضا ضمن النموذج.

قورنت نتائج التحليل بهذا النموذج مع نتائج اختبار معملي أجراه المؤلفون على كمرتين من الخرسانة المسلحة بالأبعاد الكاملة إحداهما بدون فتحة والأخرى بفتحة في منطقة القص ودرس ثنأثنير تواجد الفتحة

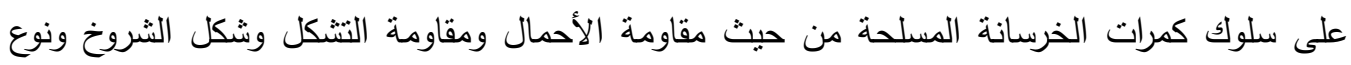
الانهيار وقد بينت المقارنة تقاربا مقبولاً. 